INDO GLOBAL JOURNAL OF

PHARMACEUTICAL SCIENCES

ISSN 2249- 1023

\title{
Colonization of Human Pathogenic Bacteria on Phyllopane of Organically Grown Solanum lycopersicum
}

\author{
Indu Gaur, Prabir K. Paul* \\ Cell and Molecular Biology Lab, J3 Block, Amity Institute of Biotechnology, Amity University Campus, Sector125, Noida, Gautam Buddha \\ Nagar, U.P. 201303, India
}

Address for Correspondance: Prabir K Paul, prabirkp@)rediffmail.com

Keywords Organic Farming; Human

Pathogenic

Bacteria;

Phylloplane;

Solanum

lycopersicum.

\begin{abstract}
The concept of organic agriculture has been accepted as novelty in Indian society, but there is no data available on the human pathogens colonizing plant parts due to such practices. Also the pattern and mechanism of their colonization needs to be understood in order to devise possible strategies for their prevention. In the present study, five of the human pathogenic bacteria- Klebsiella pneumoniae, Enterobacter ludwigii, Serratia fonticola, Stenotrophomonas maltophilia and Chryseobacterium jejuense were isolated from organically grown tomato phylloplane. Tomato plants grown under controlled aseptic conditions with $25 \pm 1^{\circ} \mathrm{C}$, $70 \%$ humidity and 12 hour L/D photoperiod were divided into 6 groups of 25 plants each and treated as follows: Group 1: K. pneumoniae; Group 2: E. ludwigii; Group 3: S. fonticola; Group 4: S. maltophilia ; Group 5: C. jejuense ; Group 6: Sterile distilled water (control). Leaf samples from above groups were collected at $0.5,2,4,6$ and 24 hours post inoculation for the colony forming unit counts $\left(\mathrm{CFU} / \mathrm{cm}^{2}\right.$ of leaf area) of individual pathogens using leaf impression method. These CFU counts were used for in vivo colonization assay and to study adherence of these pathogens individually to the tomato phylloplane. Antibiotic sensitivity testing with at least 12 antibiotics was also performed for each of these pathogens.It was observed that bacteria belonging to Enterobacteriaceaefamily showed a sharp increase in their colonization post $24 \mathrm{hpi}$, while others were inhibited. All identified bacterial species were found to be resistant to at least 4 out of total 12 antibioticstested. Based on these findings, S. fonticola was found to be most prominent colonizer, hence was studied further for understanding molecular mechanism of its interaction with tomato phylloplane. (C) 2016 iGlobal Research and Publishing Foundation. All rights reserved.
\end{abstract}

Conference Proceedings: International Conference on Advances in Plant and Microbial Biotechnology (PMB2017); JIIT, Noida: February 02-04, 2017

Indo Global Journal of Pharmaceutical Sciences( ISSN 22491023 ; CODEN- IGJPAI; NLM ID: 101610675) indexed and abstracted in EMBASE(Elsevier), SCIRUS(Elsevier),CABI, CAB Abstracts, Chemical Abstract Services(CAS), American Chemical Society(ACS), Index Copernicus, EBSCO, DOAJ, Google Scholar and many more. For further details, visit http://iglobaljournal.com 